DOI:10.17951/h.2019.53.1.29-38

\begin{tabular}{lcc}
\hline & A N N A L E S \\
UNIVERSITATIS MARIAE CURIE-SKŁODOWSKA \\
LUBLIN - POLONIA \\
SOL. LIII, 1 & SECTIO H \\
\hline
\end{tabular}

DARIUSZ DUDEK

dariusz_dudek@op.pl

Maria Curie-Skłodowska University, Faculty of Economics,

pl. Marii Curie-Skłodowskiej 5, 20-031 Lublin, Poland

ORCID ID: https://orcid.org/0000-0002-5288-6881

\title{
The significance of compliance in customer relations illustrated by the example of PGE Obrót S.A.
}

Keywords: compliance; customer relations; PGE

JEL: M14; M21; M42

How to quote this paper: Dudek, D. (2019). The significance of compliance in customer relations illustrated by the example of PGE Obrót S.A. Annales Universitatis Mariae Curie-Skłodowska, sectio H-Oeconomia, Vol. 53, No. 1.

\begin{abstract}
This paper discusses the impact of compliance principles on an enterprise's relationships with its key clients, as exemplified by PGE Obrót S.A. The theoretical section of the paper outlines compliance-related issues. The definition of the term and its essence are discussed. In addition, compliance objectives, tasks, functions and instruments are described. Moreover, the COSO framework and ISO 19600 standard is discussed in connection with compliance. On the basis of a survey, the empirical section assesses the significance of compliance in relation with the surveyed company and outlines some key findings as a result.
\end{abstract}

\section{The subject matter and objective of the paper}

Modern organizations operate in a very dynamic and volatile business environment. Enterprises seek and introduce novel instruments safeguarding them against risks emerging from their business operations. Such risk is especially valid with regard to legal regulations or loss of clients' trust. Trust is fundamental in business 
relations and constitutes a vast capital of any company. It exerts a direct impact upon the functioning of businesses and their market position. It also forms the basis for the development of long-term relations between the company and its clients, both present and prospective.

The compliance framework constitutes the newest tool aiming to ensure that the operation of a company meets the legal requirements and standards enforced in the organization. Compliance principles adopted in a particular enterprise may be and frequently are carried over onto all business partners. Suppliers and clients are obliged to follow these principles by appropriate contractual conditions or regulations incorporated into other documents. Partners' refusal to be bound by such terms may exclude them from cooperation or severely limit the number of potential clients. Despite their consistent development, compliance programmes remain a novelty on the Polish market. However, significant interest regarding the introduction of compliance principles or similar solutions has been observed among Polish entrepreneurs.

The objective of the present paper is to discuss the principles of the compliance framework and examine the impact of compliance upon the relations of PGE Obrót S.A. with their corporate clients. The following research question is posed: Did the introduction of compliance in PGE Obrót S.A. have a positive impact on its relationships with corporate clients?

\section{The essence and application of compliance}

The emergence of compliance was stimulated by strong competition, which motivated competitors to seek the limits of legal behaviour, and, at times, to imperceptibly transgress these limits. As a consequence, the compliance framework has become one of the "hard" determinants of companies' competitiveness (Gasparska \& Jabłońska-Bonca, 2019, p. 69). Undeniably, any organizational structure is at potential risk of pathological behaviour. This may stem from both individual weaknesses of the organization's employees, or pan-organizational factors - its strategy, management and work organization, as well as external circumstances and systemic factors (Kobylińska \& Folta, 2015, p. 13). The risk of non-compliance is interpreted in light of specific incidents (e.g. legal sanctions, financial losses, or the loss of credibility) which may occur due to a breach of standing legal regulations or terms outlined in documents adopted by the particular organization (Czechowska, 2016, p. 148).

The most straightforward definition of compliance denotes the compatibility of the organization's operations with legal regulations. In other words, in functional terms, compliance prevents the emergence of irregularities in the organization and its structure. This is a preliminary and simplified definition which may be modified in various ways. The related literature features a more elaborate definition. It states that compliance is the sum of means aiming to ensure that legal terms are met and statutory regulations are not breached by the enterprise, members of its various 
bodies, and by employees. Generally speaking, it revolves around the company operating within legal boundaries. A similar definition is adopted for compliance in corporations. However, in this case, the emphasis is placed upon the long-term character of the approach which warrants a proper operation of the compliance framework (Makowicz, 2011, p. 16).

In relation to companies, the compliance policy denotes that business operations meet all legal regulations, standards and policies regulating the functioning of the organization (Gnazzo, 2011, p. 538). The literature highlights the necessity of business operations being compatible with the letter and spirit of the law (Edwards, 2003, pp. 225-235).

The term "compliance" is also defined as an audit and consulting pertaining to the global legal environment of the organization. Such activities also encompass preventive and corrective measures, support of the business entity in legal actions, and development of structures and procedures, i.e. the entirety of affairs exerting an impact upon the legal liability and the image of the entrepreneur. The procedures aim to inform the board of conclusions drawn from monitoring specific areas, and to facilitate the process of selecting an adequate response (Andrzejewski, 2012, p. 259).

The management of the non-compliance risk constitutes the primary function of the compliance framework. Compliance ensures that standing law, regulations, principles and standards are adequate and clearly reflected in accurate instructions and internal procedures, and that these instructions and procedures are adequately implemented. The risk-based approach constitutes the fundamental form of preventing the non-compliance risk (Andrzejewski, 2012, p. 259). If irregularities emerge within a company, compliance aims to reorganize the enterprise so that the process ensures permanent restructuring. If the company has already been adequately reorganized, compliance-related measures are implemented to ensure irregularities never resurface (Makowicz, 2011, p. 20).

In order to systematize the objectives of compliance, primary and secondary objectives ought to be discussed. The primary objectives are relatively easy to define: they aim to prevent the emergence of a failure chain. Regardless of the adopted definition, in all cases, compliance pursues the achievement of several fundamental secondary objectives. These encompass the prevention of legal risks which may materialize in the form of sanctions and loss of the company's reputation, development of a transparent company structure, effective control and observation of the company, and the adequate documentation of the process. If compliance, regardless of the manner in which it is implemented in a particular organization, is to constitute a functional and effective system, it ought to be clearly communicated. The communication of compliance in the organization is the process of disseminating information on the enforced standing compliance framework among its stakeholders. Successful communication is one of the cornerstones of a suitable implementation of any compliance framework (Banasiak \& Sędkiewicz, 2016, p. 15). 


\section{Compliance function in an enterprise}

The functions of compliance in the company may be classified into two fundamental categories: preventive functions and repressive functions (see Figure 1).

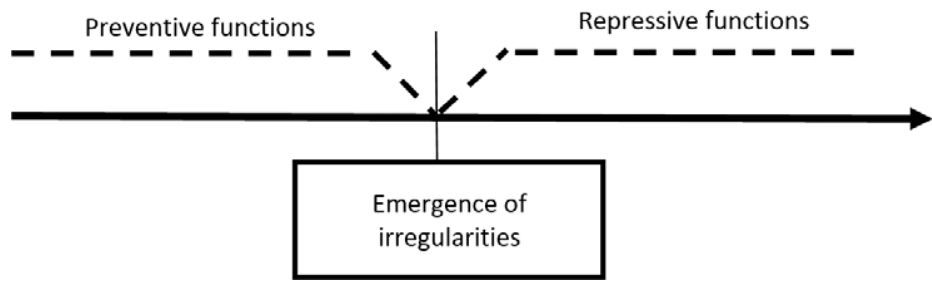

Figure 1. Fundamental functions of compliance

Source: (Makowicz, 2011, p. 20).

Prevention constitutes a critical function of compliance. An adequate and well-established compliance system will engage at the onset of any irregularities. Compliance must come into operation at the earliest possible moment and prevent even the slightest attempt at a non-compliant behaviour being pursued in the company.

Repression constitutes the second fundamental function of compliance. By means of adequate measures, the function responds to the emergence of irregularities. It aims to detect irregularities as early as possible and to contain the failure chain before the situation escapes control. Therefore, at this stage, it may be argued that the repressive function of compliance, revolving around detecting irregularities and imposing adequate sanctions, transforms into a specific preventive framework aiming to prevent the emergence of the failure chain which may prove fatal for the company.

Apart from the above-mentioned functions, compliance serves an array of specific functions beneficial for the enterprise. Figure 2 outlines the selected specific compliance functions.

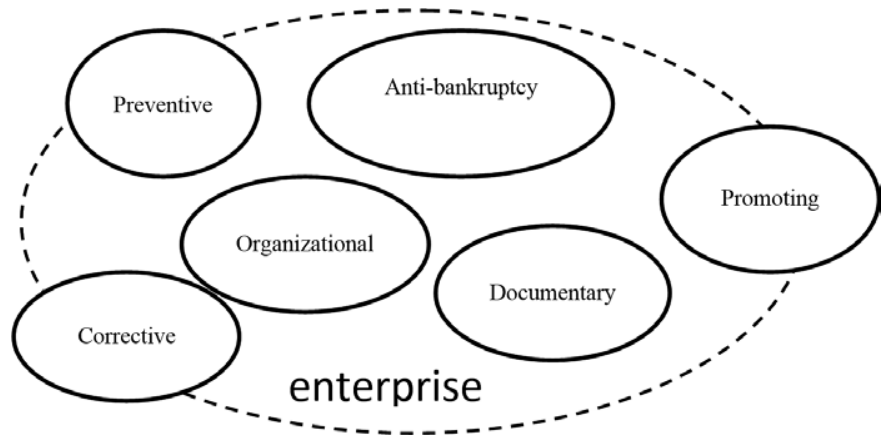

Figure 2. Selected specific compliance functions 
The corrective function of compliance revolves around reorganizing the company by developing a new compliance framework from scratch, or alternatively, improving the present system. In parallel to the corrective measures, enterprises ought to run a media campaign informing the surrounding environment that firm actions were undertaken in order to prevent any future irregularities, that these actions are a priority, and that initial results can already be observed. The promoting function constitutes the next specific function. The introduction of the compliance framework in the company may be exploited for marketing purposes. Due to the fact that informing the community about the introduction of compliance boosts trust, it may have a key impact on the company's relations with its business partners, clients and investors.

An adequate compliance framework in the company can also perform a preventive function. Compliance offers a protective shield, making the company resistant to any inappropriate actions from within the enterprise, but also impervious to any hostility emerging from without. The documentary function revolves around collecting documentation on any compliance dimensions present in the company. Not only the compliance framework itself, but also its operation and individual elements ought to be adequately documented.

Undeniably, a well-established compliance framework performs an organizational function. Frequently, in order for compliance objectives to be achieved, an extensive intervention in the company's organizational structure is required for all critical elements which may eliminate the emergence of irregularities. The system requires the company to establish a separate department or allocate an entity responsible for compliance-related tasks. Such an entity must be adequately integrated with the company. The competences of the entity ought to be clearly established and separated from the competences of the remaining departments of the enterprise. Finally, the anti-bankruptcy function enables insolvency to be prevented by the engagement of minimum resources. If well publicized, even the slightest irregularity in the company may deliver a fatal blow. In general, the function revolves around the constant monitoring of critical locations and processes but also a random inspection of locations deemed safe (Makowicz, 2011, p. 26).

\section{Enterprise risk management}

Successful compliance instruments aim to ensure that companies operate within legal boundaries. By doing so, they aim to prevent the emergence of the failure chain, i.e. the situation when irregularities emerge, are disclosed and publicized, and harm the company. Different enterprises operate in different legal environments, manufacture various products and offer various services. As a consequence, they face several risks associated with the failure to comply with legal regulations, which must take into account a compliance framework adjusted to a specific company. 
A compliance management system constitutes a system developed individually by the enterprise itself. The system undergoes constant changes. No supervision of the compliance management system can ensure its complete effectiveness. However, it is associated with the identification of the so-called weak spots. By doing so, this leads to the system being improved. Regular assessment of the adequacy and effectiveness of principles and effectiveness of the compliance management system may decrease the probability or prevent the emergence of a risk (Gertig, 2016, p. 19).

The introduction of principles is inseparable from internal control. It is facilitated by the Integrated Framework - COSO I (Figure 3). This determines the components, principles and factors required by organizations in order to manage risk effectively by implementing a system of internal control. Duties and responsibilities must be clearly defined so that each employee group understands its role in addressing the risk, control and affairs it is responsible for, as well as the principles and means of cooperation with other groups. There ought to be no gaps and unnecessary or accidental overlap of effort in addressing risk and control (Anderson \& Eubanks, 2015, p. 1). The COSO aims to ensure leadership in three interrelated fields: Enterprise Risk Management (ERM), internal control and prevention of abuse.

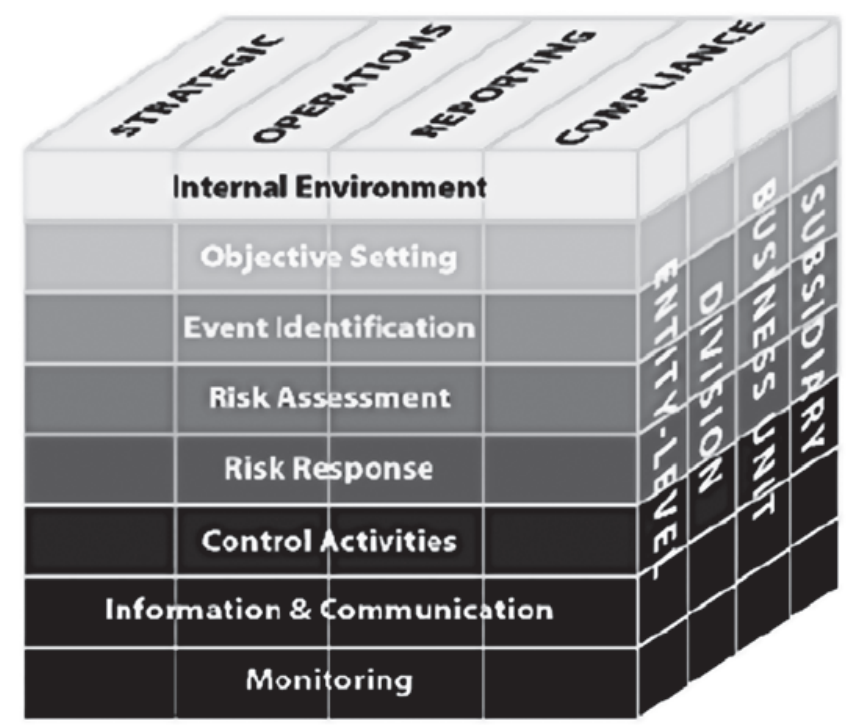

Figure 3. The COSO framework

Source: (Bright Planet, 2015).

ERM always aims to achieve its objectives and encompasses the following categories:

- Strategic: high-level objectives, adjusted and supporting the mission;

- Operational: effective and efficient application of resources; 
- Reporting: reliability of reporting;

- Compliance: compliance with applicable law and regulations.

ERM is composed of eight interrelated elements which are applied in order to achieve objectives that emerge from the organization's strategy. The elements are the following: internal environment, establishment of objectives, identification of events, risk assessment, response to the emergence of risk, control activities, information and communication, and monitoring (Mechelewski, 2008).

The COSO framework encompasses several key premises (COSO I Kontrola Wewnętrzna - Zintegrowana Struktura Ramowa, n.d.):

- Internal control is a process. It is a means to an end instead of the objective itself;

- Internal control is people-dependent. It is composed not only of the policy, manuals and forms, but the people of every organizational level;

- The role of internal control is to supply managers with a rational instead of absolute assurance that organizational objectives will be achieved;

- Internal control is focused upon the achievement of objectives in one or several separate but interrelated categories.

\section{Empirical section of the study}

The empirical section of the paper analyses the results of the study examining the impact of compliance principles upon the relations of PGE Obrót S.A. (Rzeszów branch), an electric energy supplier, with their corporate clients. The company is a part of the PGE Capital Group, among one of the largest energy sector companies in Central Europe. In Poland, PGE is the dominant enterprise in the electric energy sector as far as income and profit are concerned. Owing to the combination of own resources and energy manufacturing capacity, as well as the distribution network, PGE supplies electric energy to five million clients. The enterprise works with various types of clients - companies, institutions, local governments and households. The company operates throughout Poland. PGE's operations may be divided into two markets: the historic market encompassing the part of Poland where PGE Obrót S.A. supplies energy to clients connected to the electric grid through the intermediary PGE Dystrybucja S.A. and the national market encompassing the remaining area of the country where clients connect to the network through other entities. The main competitors of the enterprise encompass sales companies affiliated with other large energy groups operating in Poland. The groups include Enea, Tauron and Energa. The market share of the four largest suppliers is estimated at $85 \%$. PGE's share is $30 \%$, which makes the company the market leader.

In 2016, PGE Polish Energy Group embraced a compliance management system and a code of conduct. By doing so, PGE defined the most significant values and principles it aims to follow in its operations. The PGE Code of Conduct constitutes 
a collection of values and principles enforced throughout the group. The code outlines the fundamental ethical values and standards of the PGE Group. All employees, including the management, are expected to adhere to these. The code regulates the procedure for reporting irregularities in case of a breach or violation of the values and principles (GK PGE, 2018a). A further code introduced in the PGE Capital Group is the Code of Conduct for Business Partners. It defines the minimum requirements for the group's partners concerning human rights, working conditions, environment protection and the transparency of business operations (GK PGE, 2018b). Guidelines based upon the codes constitute the core of daily cooperation of all enterprises in the PGE Group with their business partners.

Empirical studies were conducted in Q1 of 2019 in the course of sales workshops. The study encompassed 24 sales partners working with key corporate clients in Poland (of the total of 26). Opinions of the sales partners in the corporate client department pertained to the cooperation with the largest recipients of PGE Obrót S.A. The study was conducted by means of a standardized survey questionnaire. Full anonymity was provided. The survey consisted of 20 questions grouped in three thematic blocks. The first pertained to presents in $\mathrm{KAM}^{1}-$ Client and Client-KAM relations. The second examined the means by which customer relations were established. The third discussed the selected compliance elements. The present paper analyses respondents' responses in the compliance-related block.

When analysing replies to individual questions from the questionnaire, it became evident that several companies operating in Poland are implementing or have already implemented compliance systems or similar frameworks based upon a code of conduct. With regard to the question concerning the application of compliance principles by clients, $71 \%$ of respondents indicated that the majority of their clients, or some of them, employ compliance principles. According to the responses, few companies (8\%) apply no compliance principles. Therefore, it may be argued that the introduction of compliance has become a standard procedure necessary for operating on the market. Clients' reactions to PGE introducing compliance indicate that the majority of them are familiar with these principles. Sales partners frequently declare that clients "understand such an approach" (58\%). Those who have never experienced the approach or do not understand it are far fewer (29\%). This picture is made complete by the following observation. Fifty percent of PGE Obrót S.A. corporate clients sporadically or frequently deny accepting presents from the company. In $80 \%$ of cases, this is motivated by the regulations enforced in the client company. Only $21 \%$ of clients do not understand sales partners' behaviour resulting from the compliance principles with regard to presents being given or accepted in particular.

Responses clearly state that the developed and implemented compliance procedures must be designed and applied so that they accurately define responsibilities emerging from these. Only $17 \%$ of respondents believe that the introduced compli-

\footnotetext{
1 Key Account Manager - person responsible for the company's key customers.
} 
ance principles are straightforward and clear. Thirty three percent believe that the procedures ought to be more specific, while $29 \%$ had no opinion on the subject. The remaining respondents $(21 \%)$ believe that the procedures were not straightforward. Respondents' responses indicate the necessity of the implemented solutions being made more precise or better communicated or interpreted for specific employee groups.

The positive impact of compliance for PGE Obrót S.A.'s image was recognized by $35 \%$ of sales partners. The remaining ones have not recognized such an impact or have not had enough experience with the operation of compliance in the company and companies they cooperate with. This was acknowledged by the belief voiced by $96 \%$ of respondents that the principles will exert a positive influence upon the company as far as work culture and occupational safety in PGE Obrót S.A. are concerned. Respondents' answers to the final question leave no doubt as to the positive impact of compliance. They observed that compliance did not have an adverse impact on their relations with corporate clients, and that they expect it to constitute one of the most significant factors helping to maintain business relations and develop new ones.

\section{Conclusions}

The results of the present study may be summarised in the following statements:

1. PGE's corporate clients responded positively to the information regarding the introduction of compliance by the company. The majority of them understand the principles and some of them introduced compliance principles or similar codes of conduct in their businesses.

2. The introduction of compliance exerted a positive impact on PGE Obrót S.A.'s image. A company based on compliance reinforces its credibility in both its relationships with business partners and, especially, with all its clients.

3. Due to the specific character of the company's activities, the rules of compliance introduced to PGE Obrót S.A. require a more precise description so that they can be efficiently executed.

4. The introduction of compliance has had a positive influence on the improvement of occupational safety and work culture in PGE Obrót S.A., which has and will have a direct impact on the enhancement of work comfort.

5. The introduction of compliance had no negative impact on customer relations. The pursuit of clear principles in mutual relations will develop and enhance them. 


\section{References}

Anderson, D.J, \& Eubanks, G. (2015). Ład organizacyjny i kontrola wewnętrzna. Wykorzystanie COSO w trzech liniach obrony. Warszawa: Instytut Audytorów Wewnętrznych.

Banasiak, H., \& Sędkiewicz, K. (2016). Intranet, newslettery i legal alerty. Czyli kilka słów o sposobach komunikacji compliance w organizacji. Compliance, 2, pp. 15-17. Retrieved from: www.instytutcompliance.pl [access: 5.02.2019].

Andrzejewski, M. (2012). Ryzyko zgodności (compliance) jako metoda ograniczania ryzyka działalności firm. In: B. Glinkowska, B. Kaczmarek (Ed.). Wspótczesne koncepcje i metody zarzadzania organizacjami - aspekty społeczne, Acta Universitatis Lodziensis, Folia Oeconomica, 265, pp. 257-271.

Bright Planet (2015). How OSINT Supports COSO Risk Management. Retrieved from: https://brightplanet. com/2015/08/how-osint-supports-coso-risk-management/ [access: 5.02.2019].

COSO I Kontrola Wewnętrzna -Zintegrowana Struktura Ramowa (n.d.). Retrieved from: http://www.pikw. pl/coso-i-kontrola-wewnetrzna-zintegrowana-struktura-ramowa,art_404.html [access: 5.02.2019].

Czechowska, D. (2016). Etyka w relacjach instytucji finansowych z gospodarstwami domowymi. Łódź: Wydawnictwo Uniwersytetu Łódzkiego.

Edwards, J. (2003). Individual and corporate compliance competence: An ethical approach. Journal of Financial Regulation and Compliance, 11(3), pp. 225-235. DOI: 10.1108/13581980310810534.

Gasparska, W., \& Jabłońska-Bonca, J. (Ed.) (2019). Biznes. Prawo. Etyka. Warszawa: Wydawnictwo Akademickie i Profesjonalne.

Gertig, M. (2016). Zbadajmy systemy zarządzania compliance! Czy i w jaki sposób można zbadać efektywność systemów zarządzania zgodnością? Kto i kiedy powinien tego dokonać?. Compliance, 1, pp 18-19. Retrieved from: www.instytutcompliance.pl [access: 5.02.2019].

Gnazzo, P.J. (2011). The chief ethics and compliance officer: A test of endurance. Business and Society Review, 116(4). DOI: 10.1111/j.1467-8594.2011.00396.x.

Kobylińska, A., \& Folta, M. (2015). Sygnaliści - ludzie, którzy nie potrafia milczeć. Doświadczenia osób ujawniajacych nieprawidłowości w instytucjach i firmach w Polsce. Warszawa: Fundacja Instytut Spraw Publicznych.

GK PGE (2018a). Kodeks Etyki GK PGE. Retrieved from: https://www.gkpge.pl/Compliance [access: 5.02.2019].

GK PGE (2018b). Kodeks Postępowania dla Partnerów Biznesowych Spółek GK PGE. Retrieved from: https://www.gkpge.pl/Compliance [access: 5.02.2019].

Makowicz, B. (2011). Compliance w przedsiębiorstwie. Warszawa: Oficyna a Wolters Kluwer Business.

Mechelewski, T. (2008). Zintegrowane Zarzadzanie Ryzykiem - COSO II - standard nie tylko popularny... Retrieved from: http://www.pbsg.pl/coso-ii-standard-nie-tylko-popularny [access: 5.02.2019]. 